\title{
IKONOGRAFIA WCIELENIA W SZTUCE WCZESNOROMAŃSKIEJ I ROMAŃSKIEJ NA WYBRANYCH PRZYKŁADACH SCEN BOŻEGO NARODZENIA
}

Historia sztuki jako nauka stworzyła w 2. poł. XIX wieku modele pojęciowe, które służą jako narzędzia badawcze stawianym kwestiom dotyczącym formy, wyrazu stylistycznego oraz treści dzieła sztuki. Kościół średniowieczny rozumiał funkcję dzieła sztuki jako medium bezpośredniego przekazu wiary unaocznionej w historii świętej lub wizerunku podległemu czci wiernych. Interesujący nas problem wcielenia w sztuce wczesnośredniowiecznej, wpisany jest głęboko w myśl teologiczną oraz dewocję ówczesnego Kościoła, przenikniętego chrystologiczną i mariologiczną tkanką. Sztuka wczesnego średniowiecza zamykającego się pomiędzy VII a połową wieku XI, rozwijała się najbardziej intensywnie na terenach Galii, Hiszpanii, Italii, Germanii oraz na Wyspach Brytyjskich łącznie z Irlandią. Dominująca tutaj łacińska orientacja religijna na różny sposób, ale wyraziście przeniknięta była osmozą tradycji śródziemnomorskiej z orientalną, podtrzymywaną przez Bizancjum. Dlatego też interesujący nas motyw w sztuce wczesnośredniowiecznej stanowi kanon złożony, którego korzenie sięgają wzorów wczesnochrześcijańskich oraz wczesnobizantyńskich. Pierwsze wnosiły silne poczucie formy, która gwarantowała czytelną treść. Według drugiego kręgu kultury, w materii sztuki uwięziona jest idea, która określa istotę obrazu - zwłaszcza obrazu postaci boskiej ${ }^{1}$. Rozumienie dogmatu wcielenia, dotykało bezpośrednio owego tajemniczego związku idei ducha oraz materii dzięki której objawiona może zostać tajemnica Boga. Tak rozumiana sztuka religijna mogła łączyć się z racją teologiczną materialnego objawienia się transcendentnego Boga. W swojej istocie bowiem określał wizualnie pojmowane relacje pomiędzy „obrazem a podobieństwem” jako jedyny rodzaj więzi pomiędzy Bogiem a człowiekiem ${ }^{2}$. Z tego więc powodu przenikał wiele znaczących wątków ikonograficznych sztuki, stając się jednocześnie dlań podłożem sensu materialnego. W szczególnie bliskiej jedności pozostawała

\footnotetext{
${ }^{1}$ J. Meyendorff, Teologia bizantyńska. Historia i doktryna, thum. J. Prokopiuk, Warszawa $1984,58 \mathrm{nn}$.

${ }^{2}$ Por. tamże s. $52 \mathrm{nn}$. 
idea sztuki: jako nieustanne przenikanie niematerialnej idei zamkniętej w materii, z ideą wcielenia jako zmysłowe objawienie się Boga w Chrystusie.

Zmuszeni jesteśmy programem konferencji, aby szeroki horyzont, jaki wykreśla ikonografia wcielenia, zawęzić do charakterystycznego typu obrazów Bożego Narodzenia, w których dramaturgia rozgrywana jest w jedności z innymi wydarzeniami - Śmierci - Zmartwychwstania - Eucharystii. Podłożem tego rodzaju scen było bizantyńskie rozumienie wcielenia Chrystusa, jako zdarzenia w czasie, a zarazem zdarzenia o wymiarze transcendentalno-kosmicznym ${ }^{3}$. Myśl tę wyrażały teksty teologiczne, zaś rozpowszechniane były w pieśniach, hymnach i modlitwach Kościoła. Należy do nich jeden z wczesnych hymnów śpiewanych podczas Nieszporów Bożego Narodzenia: „Każde stworzenie, które uczyniłeś, składa Ci dzięki: aniołowie ofiarują ci hymn, niebiosa gwiazdę, magowie swoje dary, pasterze swój podziw, ziemia jaskinię, a my ofiarujemy Dziewicę Matkę." ${ }^{4}$ Pomiędzy stworzeniem a wcieleniem jest tutaj ukazana nierozerwalna więź, która podobna jest do tej, jaka zaistniała w pierwszych dniach stworzenia. Odpowiednikiem pieśni bożonarodzeniowych były hymny wielkopiątkowe, w których również było wyrażone zaangażowanie całego stworzenia w śmierć Chrystusa.

Narodzenie Chrystusa we wczesnych obrazach sztuki określał także inny aspekt podkreślający nie-ziemskie narodziny człowieka. Było nim zstępowanie, pozostające w jedności z momentem zstapienia Ducha Świętego. Kolejnym członem współtworzącym sens Bożego Narodzenia była Eucharystia składana za Kościół, w której Kościół uczestniczy.

Sztuka w swojej naczelnej funkcji dydaktycznej podejmując naukę Kościoła, przeobrażała teksty w artystyczną formę. Tak też interesujące nas obrazy wcielenia znalazły swoje uobecnienie w scenach Narodzenia Chrystusa, połączone z ideą śmierci oraz stałą obecnością ciała Chrystusa w Eucharystii. Taki wielowątkowy obraz Bożego Narodzenia przekazały nam zabytki, zarówno bizantyńskiego jak i łacińskiego Kościoła. Różnicowane w rozwiązaniach szczegółowych, zachowały żywotność w sztuce aż do czasów dojrzałego średniowiecza, przełomu XII i XIII wieku, kiedy to nastąpiła ich kulminacja i monumentalizacja w rzeźbie katedr gotyckich.

Chcąc wskazać na dojrzałe wzory tak rozumianej sceny, należałoby wymienić znane przykłady jak: kaseta - relikwiarz na Ziemię Świętą, powstała w kręgu palestyńskim z pocz. V wieku (obecnie przechowana w Museo Sacro na Watykanie, por. il. 1, 1/a), dyptyk z Mediolanu z pol. V wieku (Mediolan, Muzeum Katedralne, por. il. 2), dyptyk z Murano z pocz. VI wieku (Murano, katedra, por. il. 3), tron biskupa Maksymiana w Rawennie z poł. VI wieku (Muzeum Arcybiskupie w Rawennie, por. il. 4). Ukazane tam sceny Bożego Narodzenia,

\footnotetext{
${ }^{3}$ Por. tamże s. 196.

${ }^{4}$ Por. tamże s. $38 \mathrm{nn}$.
} 
wprowadzają zdarzenie historyczne do szerszego kontekstu dogmatycznego: chrystologii oraz mariologii. Maria ukazana jest w tych scenach jako Theotokos - Matka Boga; ten fakt tłumaczy znaczne oddalenie Maryi od Dzieciątka, zaś na dyptyku z Murano, Maria - Theotokos wypełnia centralną część powierzchni dzieła.

Miejscem złożenia Jezusa jest żłób w kształcie grobu, a ten przywołuje kształt prostego, murowanego ołtarza. Najdobitniej ukazują to dzieła z Murano oraz katedra Maksymiana. Owe proste, czytelne formy zawierają konotacje treściowe, wychodzące poza obręb ewangelicznego opisu Bożego Narodzenia. Mimo pewnych różnic podyktowanych materiałem, istnieje w wymienionych dziełach związek Bożego Narodzenia ze śmiercią Chrystusa. Na kasecie z Watykanu, scena ta wypełnia całą środkową jej część, którą na dyptyku z Mediolanu obrazuje Baranek Boży w wieńcu zwycięskim. Na ikonie pochodzącej z Synaju z VIII/IX wieku (il. 5) do Jezusa złożonego na ołtarzu zbliżają się pasterze, zaś Maryja leżąca obok, łączy dwa zdarzenia: Narodzenie ze sceną kąpieli Dzieciątka ukazanej u dolnej części kompozycji.

Różnie sytuowany jest św. Józef: zbliżony do sceny kąpieli lub razem z Maryją, umieszczony jest u podstawy ołtarza, jak to ukazuje kolejna ikona powstała w kręgu palestyńskim w VII wieku (lub jak niektórzy przypuszczają w. IX, por. il. 6). Scena z relikwiarza w kształcie krzyża, powstałego w Palestynie (lub Bizancjum na przełomie VIII/IX wieku, Watykan, Museo Sacro, por. il. 7), potwierdza ikonograficzny kanon, jaki utrzymywany był w obrębie sceny Bożego Narodzenia, asymilującej szeroko rozumianą treść wcielenia oraz śmierci Chrystusa, której poddane było realne ciało Pana.

Już w tym najwcześniejszym, zaprezentowanym wybiórczo, repertuarze obrazowym zachowane są podstawowe elementy pozwalające wskazać na sens interpretacji wcielenia. Istotnym elementem, wiążącym złożoną treść naszych obrazów, jest usytuowanie postaci: Maryi, Dzieciątka i św. Józefa. Miejscem centralnym jest grota - jaskinia, która jednak ogarnia tylko Jezusa, a nie całą świętą grupę. Zanurzona jest ona w świetle, które napełniając grotę opromienia Jezusa. W ten sposób unaocznione zostało światło Logosu z Ewangelii św. Jana. Śpiewający aniołowie ukazani w głębokim pokłonie, dopełniają owej mistyki ponadziemskich narodzin Boga.

Jaskinia - grób była także miejscem złożenia Chrystusa po zdjęciu z krzyża, tutaj też nastąpiło Zmartwychwstanie w chwale. Dlatego też umieszczanie wyłącznie nowo narodzonego Chrystusa w grocie, zaś postaci Maryi oraz św. Józefa poza jej obrębem, wskazuje na świadomie wykreowaną zbieżność miejsca narodzin i śmierci, co wymienione przykłady, zwłaszcza ikona z Synaju (il. 5), podkreślają. Męka Chrystusa, złączona ze scenami Bożego Narodzenia przywołana zostaje także w prostym znaku, jakim jest nimb krzyżowy wokół głowy Jezusa, który niezmiennie zaznaczany pozostał w postaciach Chrystusa w całej sztuce wczesnośredniowiecznej. 
Dwojaka, ludzka i boska natura Chrystusa, podkreślana w wypowiedziach wszystkich niemal soborów pierwszych wieków, musiała być akcentowana w sztuce również elementami wizualnymi, aby unaocznić naturę wcielenia Chrystusa jednoznacznie obrazowo, jednocześnie uzmysłowić bezsprzecznie pod względem teologicznym. Drugim więc nieodłącznym ogniwem tych scen jest grób, przedstawiany w formie murowanej, odpowiadającej ówczesnym ołtarzom. Celem tego plastycznego zabiegu, było wprowadzenie do wątku Bożego Narodzenia idei Uczty Mistycznej ciała Chrystusa, objawiającej się każdorazowo w czasie Eucharystii ${ }^{5}$. Ikona z Synaju (por. il. 6) ukazuje w ołtarzu wydrążenie, będące miejscem na palącą się lampkę, widoczne wcześniej w reliefie tronu Maksymiana (il. 4). Grota Narodzenia Jezusa jest jednocześnie, dzięki ołtarzowi, grotą grobu i Zmartwychwstania. Zatem elementem wiążącym jest ziemia - grota, która wydała Jezusa przytaczając słowa hymnu, jednocześnie jest powtórnym wyjściem w czasie Zmartwychwstania. Dlatego usytuowanie w grocie miejsca narodzin połączone zostało, dzięki ołtarzowi, z miejscem śmierci i Zmartwychwstania.

Przesłanie o cielesności Chrystusa spowodowało rozszerzenie treści Bożego Narodzenia do kolejnej sceny - kąpieli Dzieciątka, która jest zapowiedzią chrztu Chrystusa. Istotę tego związku obserwujemy na obrazach: kasety z Palestyny (il. 1), krzyża relikwiarzowego z Watykanu (il. 7), dyptyku z Mediolanu (il. 2), gdzie scena kąpieli Dzieciątka ukazana została w bliskości ze sceną chrztu Chrystusa. Kąpiel Dzieciątka była pierwotnie związana ze wschodnim typem Bożego Narodzenia, rozpowszechniona następnie w łacińskiej sztuce wczesnośredniowiecznej, zwłaszcza Italii ${ }^{6}$.

Przed- i wczesnoromański repertuar ikonograficzny wcielenia miał zatem swoją bogatą pod względem ikonograficznym genezę w sztuce bezpośrednio ją poprzedzającą. Do tej tradycji sięgać mogła bezpośrednio sztuka okresu karolińskiego. Luksusowym tego przykładem jest okładka Ewangeliarza z Lorsch z roku ok. 810, powstała w kręgu cesarskim w Akwizgranie (Londyn, Victoria \& Albert Museum, por. il. 8). Scena Bożego Narodzenia nie przypadkiem złożona jest $\mathrm{z}$ trzech sekwencji kompozycyjnych. Maryja z Józefem ukazani są z lewej strony, na tle prostej architektury symbolizującej Betlejem. W części środkowej, a więc centralnej, ukazane zostało Dzieciątko złożone na ołtarzu grobie w obrębie architektury nawiązującej do znanych wówczas modeli Grobu Pańskiego. Wół i osioł - zwierzęta bezpośrednio łączące się z opisem Bożego Narodzenia odnoszone były również pod względem typologicznym do wydarzeń Pasji Chrystusa. Osioł obecny jest również w scenie wjazdu do Jerozolimy, zaś wół symbolizował ofiarę Chrystusa.

${ }^{5}$ Por. A. Läpple, Eucharystia. Ustanowienie, historia, uczestnictwo, tłum. M. Ruta, Kraków $1997,55 \mathrm{nn}$.

${ }^{6}$ Scena ta jest obecna zarówno w malarstwie freskowym, jak i mozaikach XI i XII wieku. 
$\mathrm{Z}$ prawej strony omawianego reliefu znajduje się scena Objawienia pasterzom, którą wczesne średniowiecze identyfikowało z objawieniem ludowi. Pasyjne konotacje dopełnia znaczący gest Maryi, która tutaj wskazuje na Jezusa, a w identyczny sposób powtarzany był w scenach Ukrzyżowania np. kościoła Santa Maria Antica w Rzymie lub na ikonie z Synaju z V wieku ${ }^{7}$.

Złotnictwo, drobna plastyka z kości słoniowej i alabastru, były rodzajem transferu łączącego sztukę bizantyńską z łacińskim obszarem artystycznym. Na dyptyku z pocz. IX wieku (il. 9, 9/a) powiększony został repertuar scen powiązanych z Bożym Narodzeniem. Wcielenie ma swoje antycypacje w wydarzeniu Zwiastowania oraz swoje następstwa w Męce Pańskiej, unaocznionej w tym dziele w scenie Ukrzyżowania oraz Zmartwychwstania, które wprowadza scena Kobiet u Grobu Pańskiego. W górnej części dyptyku czterej ewangeliści: Mateusz, Marek z lewej strony oraz Łukasz i Jan z prawej, odpowiadają opisanym wydarzeniom w tekstach swoich Ewangelii.

Znamienne w tym dziele jest miejsce Bożego Narodzenia nawiązujące niewątpliwie do ołtarza, lecz jego kształt przybrał tutaj formę niskiej kolumny. Symetrycznie z dwu stron siedzą Maryja oraz św. Józef, zaznaczona jednakże została różnica siedzisk - tronu w wypadku postaci Maryi oraz niskiego taboretu dla postaci Józefa. Bezpośrednio nad Dzieciątkiem pochylają się wół i osioł, ponad którymi unosi się anioł z rozpostartymi skrzydłami. W samym szczycie arkady zamykającej scenę, umieścił artysta mikroskopijnie wyrzeźbione miasto, zamknięte murem obronnym z bramami i basztami ${ }^{8}$. Historyczne wydarzenie Bożego Narodzenia przybrało tutaj charakter plastycznie zaprezentowanego ,traktatu teologicznego”, w którym zaakcentowana została istota Osoby Chrystusa jako Początku - w wydarzeniu Narodzenia i Powtórnym Przyjściu w wizji Nowego Jeruzalem.

Analogiczny kanon wybranych scen ukazany został na pozłacanej oprawie z Akwizgranu z Maryją Hodegetrią w części środkowej (przełom X/XI wieku, il. 10): Zwiastowanie, Boże Narodzenie, Ukrzyżowanie i Kobiety u Grobu, stanowią ramy obrazowe dla ikony Maryi z Chrystusem w typie Salwator Mundi, trzymającym zwinięty zwój w prawej dłoni. Ta precyzyjnie wybrana spójność czterech wydarzeń z życia Chrystusa określa wcielenie w perspektywie Objawienia Apokaliptycznego, co potwierdzają istoty apokaliptyczne skupione w centrum oprawy. Na fragmentarycznie zachowanych plakietkach $\mathrm{z}$ kości słoniowej, przechowywanych w zbiorach katedralnych w Tournai, z roku ok. 900 (il. 11), Boże Narodzenie umieszczone zostało w pomieszczeniu architektonicznym, w którym wstawiono żłóbek w kształcie ołtarza. Maryja

\footnotetext{
${ }^{7}$ Por. W. Nyssen, Frühchristliches Byzanz, Trier 1978 passim; H. Belting, Bild und Kult, Berlin 1987 passim.

${ }^{8}$ Por. N. Schneider, Civitas. Studien zur Stadttopik und zu den Prinzipien der Architekturdarstellung im frühen Mittelalter, Münster 1972, $14 \mathrm{nn}$.
} 
spoczywa na łożu u jego podstawy, wskazując gestem dłoni na Syna. Zamyślona postać św. Józefa dopełnia symetrii sceny, aczkolwiek pozostaje poza miejscem żłóbka. Forma architektoniczna tej kunsztownie wypracowanej budowli przypomina ówczesne cyboria, nieodłącznie związane z ołtarzami. Zatem ostateczny zamysł sceny wprowadza ideę związku wcielenia z Eucharystią̧

Oprawy Ewangeliarzy zobowiązywały, ze względu na ich funkcje i tym samym kosztowność materiału, do precyzyjnie przemyślanych pod względem teologicznym kompozycji; stanowiły integralną część świętego słowa spisanego i zarazem komentarzy ówczesnych, które podkreślały łączność wcielenia z sensem Logosu. Tendencje do rozbudowy narracyjnej tkanki Bożego Narodzenia zaobserwować można w obrazach powstałych w 2. poł. IX wieku, czego przykładem są następujące dzieła: oprawa $\mathrm{z}$ kości słoniowej wykonana w szkole klasztornej w Metzu ok. 830 roku, obecnie we Frankfurcie (il. 12), dyptyk z kości słoniowej z Mediolanu z końca X i pocz. XI wieku (il. 13) oraz oprawa Ewangeliarza z Monachium (il. 14). Tradycje bizantyńskie splatają się z tendencjami łacińskimi w doborze scen. Przykładowo obecne są dwie korespondujące ze sobą sceny: Kąpiel Dzieciątka oraz Chrzest Chrystusa (il. 13 i 14). Na oprawie Ewangeliarza z Metzu (il. 12) ukazany został sceniczny kanon do tej pory niespotykany. Scena centralna ukazuje wydarzenie Pierwszego Kuszenia Chrystusa, zaś wokół niej rozwijają narracyjny cykl sceny zaczynające się Zwiastowaniem, zaś kończy wydarzenie Trzech Króli ${ }^{10}$. Boże Narodzenie ukazane zostało w dwóch warstwach scenicznych: w górnej z postaciami Maryi i Józefa stojącego u wezgłowia oraz postacią pasterza w tle. W dolnej części tej sekwencji zdarzenia, złożone zostało Dzieciątko w prostym żłobie. Odwrócone zostały zatem kierunki w układzie Maryi, Jezusa i Dzieciątka. Wyjaśnieniem tego faktu jest zróżnicowana architektura: stajni w części górnej, zaś w części dolnej zastosowana została klasyczna forma arkady, detal architektury świątynnej. Ponad postacią Dzieciątka artysta zarysował wiszący przedmiot, który można identyfikować $z$ lampą zawieszoną nad żłóbkiem jak nad ołtarzem. Taki motyw ołtarza potwierdzają ówczesne obrazy Mszy św. Potwierdza to przykładowo miniatura $z$ Ewangeliarza Barnwarda ${ }^{11}$. Sceneria tak wypracowanego miejsca złożenia Dzieciątka wskazuje na ołtarz, sama zaś architektura odsyła do form krypt, znanych już w budownictwie karolińskim.

Sztuka X i pocz. XI wieku dzięki dynastii Ottońskiej skoligaconej z dworem w Konstantynopolu, jeszcze wyraźniej wprowadzała motywy bizantyńskiej sztuki, czy to dzięki licznym importom gotowych dzieł, czy to dzięki asymilacji motywów w obrębie łacińskiej tradycji stylistycznej. Kodeks Arcybiskupa Eg-

\footnotetext{
${ }^{9}$ Por. J. Meyendorff, dz. cyt. s. 240 nn.

${ }^{10}$ Por. R. Steenbok, Der kirchliche Prachteinband in frühen Mittelalter.Von den Anfängen bis zum Beginn der Gotik, Berlin 1965, nr kat. 18, s. 87-88.

11 Por. P. Skubiszewski, Malarstwo europejskie w średniowieczu, t. 1: Malarstwo karolińskie i przedromańskie, Warszawa 1973, s. 97.
} 
berta powstały w ośrodku trewirskim ok. 980 roku jest klasycznym przykładem adaptacji form bizantyńskich przy jednocześnie podejmowanych wysiłkach tworzenia własnego języka form sztuki, adekwatnych do podejmowanej treś$\mathrm{ci}^{12}$. Sceny przemawiają oszczędnymi, acz wyostrzonymi szczegółami takimi, jak ekspresja oczu lub wyrazistość rysunku gestykulującej dłoni. W skondensowanej formie przekazywały rozwiniętą pod względem teologicznym treść obrazu. Boże Narodzenie we wspomnianym Ewangelistarzu biskupa Egberta (Trewir, Stadtbibliothek, cod. 24, por. il. 15) wprowadza w nowy sposób zakomponowaną ideę Logosu w osobie Dzieciątka. W uderzający sposób bowiem ukazany został Chrystus w młodzieńczych, a zwyczajowo ukazywanych niemowlęcych kształtach ${ }^{13}$. Jawi się $w$ scenie inne dychotomiczne znaczenie szczegółów. Żłóbek jest zarazem sarkofagiem, pieluszki implikują bandaże, zaś wokół głowy zaznaczony jest nimb krzyżowy. Maryja pochyla się delikatnie nad Synem w analogicznym układzie kompozycyjnym, jaki widoczny jest w scenie Złożenia do grobu, ukazanej w tymże kodeksie. Malarz zrezygnował z groty, umieszczając żłóbek w obrębie linii murów obronnych, w głębi natomiast świątynna architektura, będąca tłem dla świętej grupy, jest zarazem miejscem dla osła i wołu ${ }^{14}$. Złożone ciało Chrystusa w żłobie - sarkofagu jest jednocześnie ciałem mistycznym. Liturgiczny charakter potęguje także chór aniołów zstępujący z nieba, zwiastując pasterzom narodzenie Chrystusa - Logosu. Górna część architektonicznej zabudowy odpowiada w swoim stylu tej, którą ukazał artysta oprawy z Metzu (por. il. 12).

Miniatura z kodeksu Egberta zapowiada bardzo nieśmiało zmiany, które nastąpią później w dojrzałym średniowieczu. Dotyczą one układu postaci Jezusa i Maryi, zbliżenia Matki i Syna, a w konsekwencji ukazania uczucia macierzyńskiego Maryi, co nastąpi w dojrzałym średniowieczu. Najbliższą analogią do kompozycji z Ewangelistarza Egberta jest miniatura z Missale Roberta wykonanego w opactwie w Jumieges w latach 1006-1023 (Bibl. Rouen, il. 16) ${ }^{15}$. Kunsztowna arkada stanowi ramę dla sceny, w której Maryja oddzielona jest od Jezusa w inny jednak sposób aniżeli czyniła to sztuka bizantyńska. Tutaj łoże z Maryją umieścił artysta powyżej żłóbka - ołtarza, obok którego czuwa św. Józef. Sposób przedstawienia Dzieciątka oraz miejsce Jego złożenia nasuwa wyraźne zbliżenie z obrazem tronu - Etimasija - znanego z Bizancjum, tronu paruzji. W obrębie sztuki lacińskiej wyeksponowana została scena Paruzji na frontispisie do Apokalipsy w I Biblii Karola Łysego (fol. 415v, Paryż, Bibl. Nat. MS lat, 1). Typ tronu z oparciem oraz zwierzęta: baranek i lew przypominają styl ukazania wołu i osła opartych o miejsce złożenia Dzieciątka omawianej

12 Por. R. Calkins, Iluminated books of the Middle Ages, London 1983, 146.

${ }^{13}$ Inne przykłady postaci Chrystusa - Logosu zob. jw. passim.

14 Por. Schneider, dz. cyt. s. $25 \mathrm{nn}$.

15 Por. M. Rickert, Painting in Britain the Middle Ages, London 1954, s. 45. 
miniatury ${ }^{16}$. Zamiast księgi z tronu - Paruzji, tutaj jest złożony Jezus rozumiany jako Logos, czyli Słowo które stało się ciałem.

Apokaliptyczny wątek złączony z treścią wcielenia zobrazowany został na miniaturze w Księdze Perykop Henryka II (il. 17) ofiarowanej katedrze w Bambergu w roku 1012 przez cesarza Henryka II i jego żonę Kunegundę (Monachium, Bayerische Staatsbibliothek, Clm. 4452, fol. $8 \mathrm{v})^{17}$. Tutaj jeszcze bardziej zatarte zostały obrazowe, zmysłowe formy określające Boże Narodzenie. Zamiast Dzieciątka ukazana jest młodzieńcza postać Chrystusa z nimbem krzyżowym. Półleżąca pozycja identyczna jest z pozycją Maryi, która wskazuje na Syna, podobnie jak czyni to św. Józef. Żłóbek podtrzymuje anioł na wzór starożytnych Atlantów, co sprawia, że scena przybrała charakter $u c z t y$ mistycz$n e j$. Wzmacniają ją inne komponenty, wyraźnie świadomie wprowadzone do obrazu. Lewa dłoń Maryi została ukryta pod płaszczem, odpowiednio do znanej wówczas symbolicznej wykładni lewej i prawej strony - także lewej i prawej dłoni. Prawa wzorowana na Prawicy Pańskiej, znaczyła Dobro, a nawet transcendencję, lewa natomiast określała symbolicznie ziemię i grzech ${ }^{18}$. Aby więc wzmocnić Boski związek, jaki łączy Maryję z Synem, artysta świadomie ukrył pod płaszczem lewicę Matki Boga. Obie dłonie natomiast zostały wyeksponowane w postaci św. Józefa, ponieważ Boskie Wcielenie wiązane było bezpośrednio tylko z Maryją. Unoszenie przez anioła ciała Chrystusa łączy się znaczeniowo z tekstem wypisanym na stronie recto, odnoszącym się do Ewangelii św. Jana, zaczynającym się od słów „In principio erat verbum”. Narodzenie Chrystusa ukazane zostało tutaj jako „zstąpienie Słowa” i temu podporządkowane zostały wszystkie postaci sceny.

Bezpośredni związek ze słowami Ewangelii św. Jana określił również kompozycje obrazu Bożego Narodzenia w Ewangeliarzu opatki Uty, powstałym w skryptorium w Regensburgu w latach 1002-1025 (il. 18) ${ }^{19}$. Młodzieńcza postać leżąca na ołtarzu zawinięta jest w bandaże, aby w ten sposób nawiązać jednoznacznie do faktu Narodzenia i Śmierci, a przez śmierć do Zmartwychwstania Jezusa. W scenie tutaj ukazanej nie ma postaci Maryi (il. 18/a), aby głębiej podkreślić sens Logosu, a nie cielesnego narodzenia Dzieciątka. Na karcie ze św. Łukaszem w tymże Ewangeliarzu, Boże Narodzenie ukazane jest z postacią Maryi (il. 19, 19/a), ponieważ autor Ewangelii nie pominął Maryi w opisie wcielenia. Uproszczoną, acz czytelną wersją Janowego obrazu, jest miniatura Ewangeliarza Liessies z 1146 roku (il. 20).

${ }^{16}$ Por. R. Calkins, dz. cyt. s. 157.

17 Tamże.

18 Na temat symboliki zasłoniętej ręki por. T. Dobrzeniecki, Nubijska Maiestas Domini $z$ katedry w Faras $w$ Muzeum Narodowym $w$ Warszawie, „Rocznik Muzeum Narodowego w Warszawie" 31(1987) passim.

${ }^{19}$ Por. A. Boeckler, Deutsche Buchmalerei vorgotischer Zeit, München 1952, 56. 


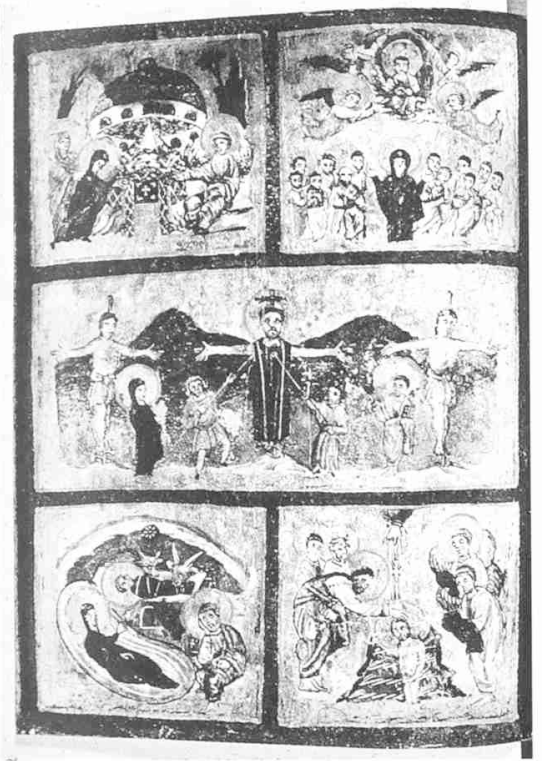

Ilustracja 1

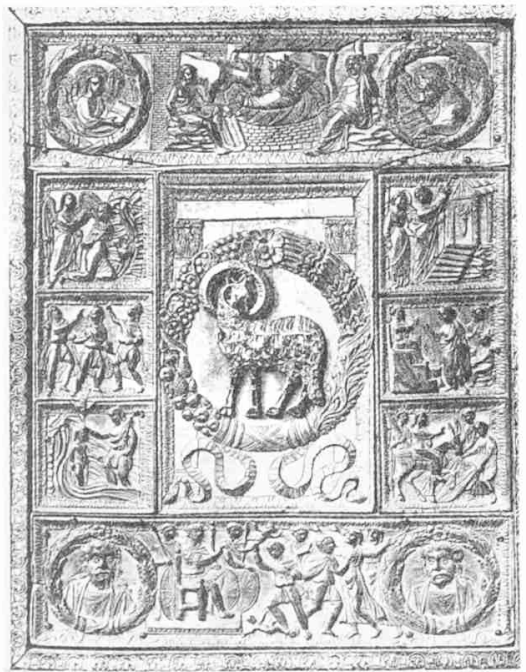

Ilustracja 2

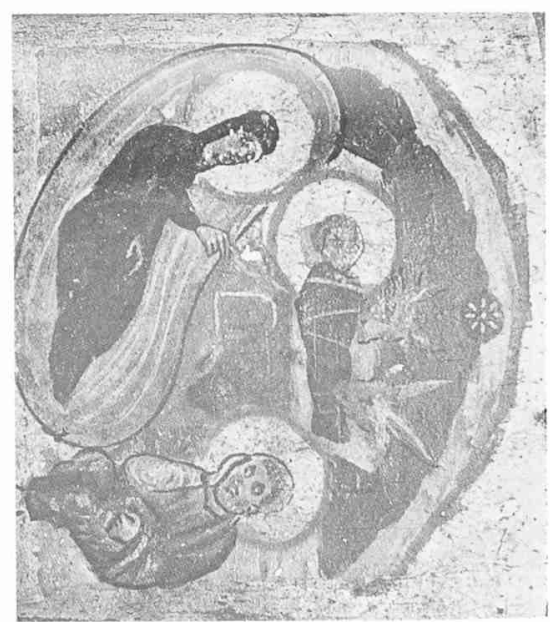

Ilustracja 1a

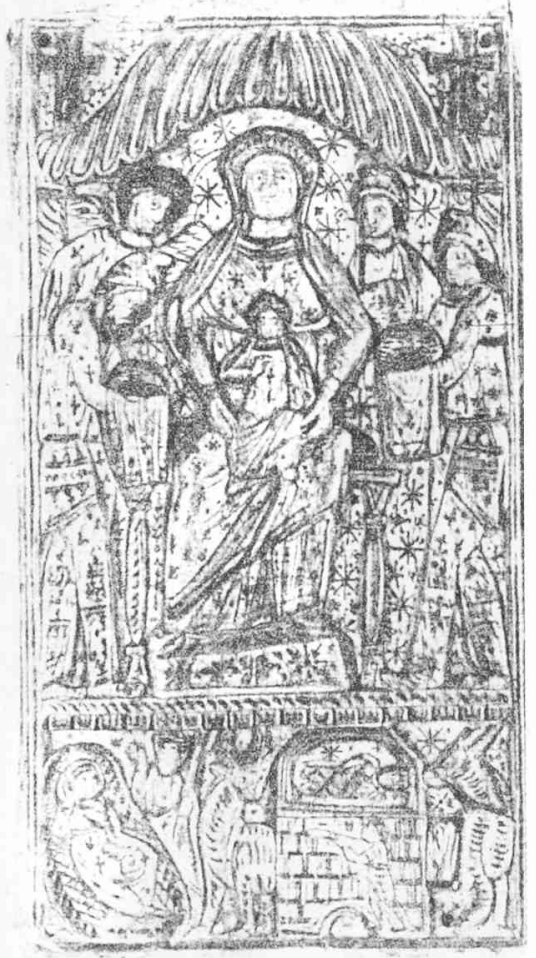

Ilustracja 3 


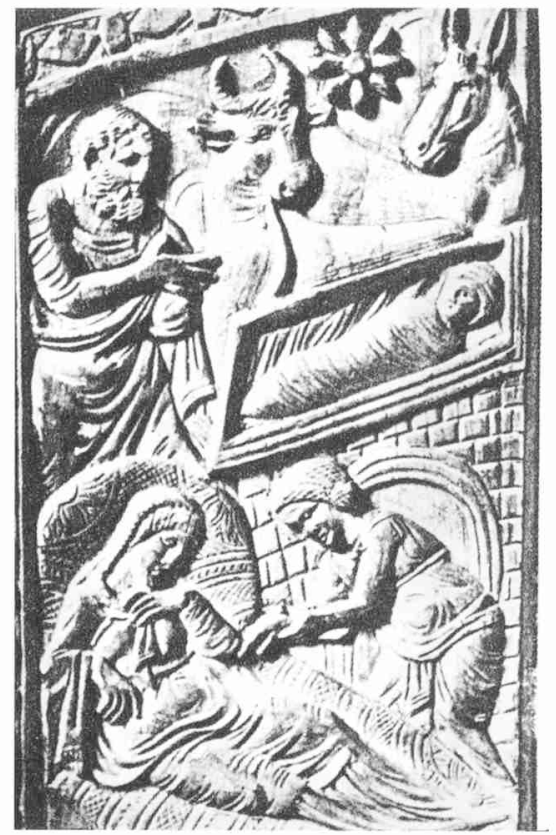

Ilustracja 4

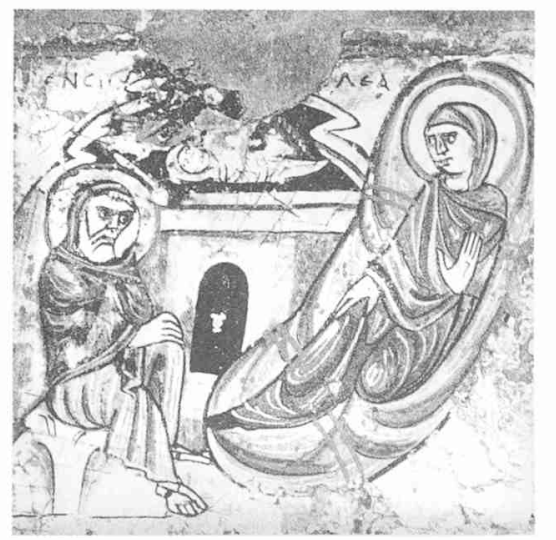

Ilustracja 6

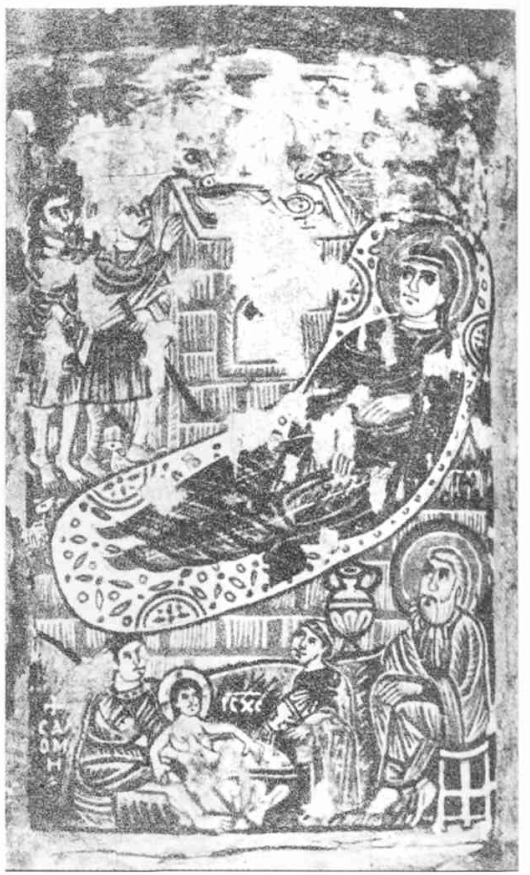

Ilustracja 5

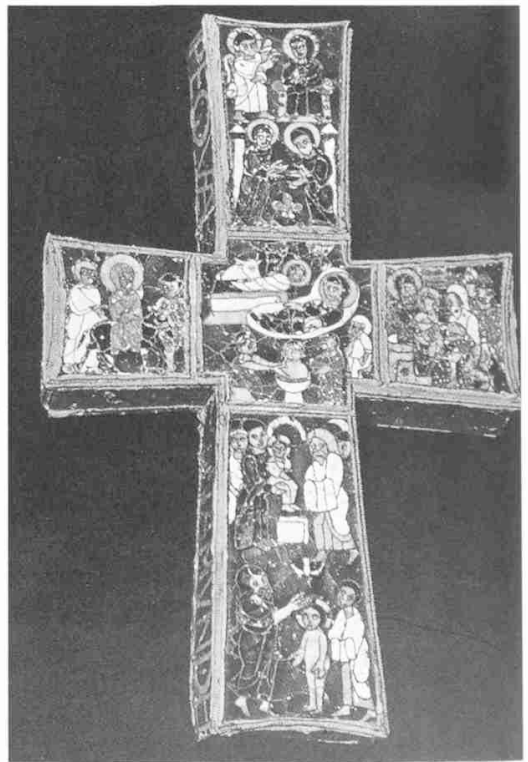

Ilustracja 7 


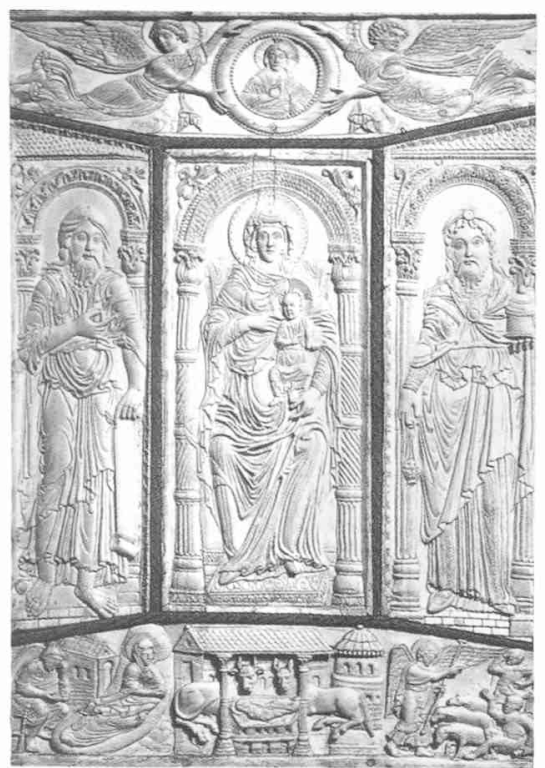

Ilustracja 8

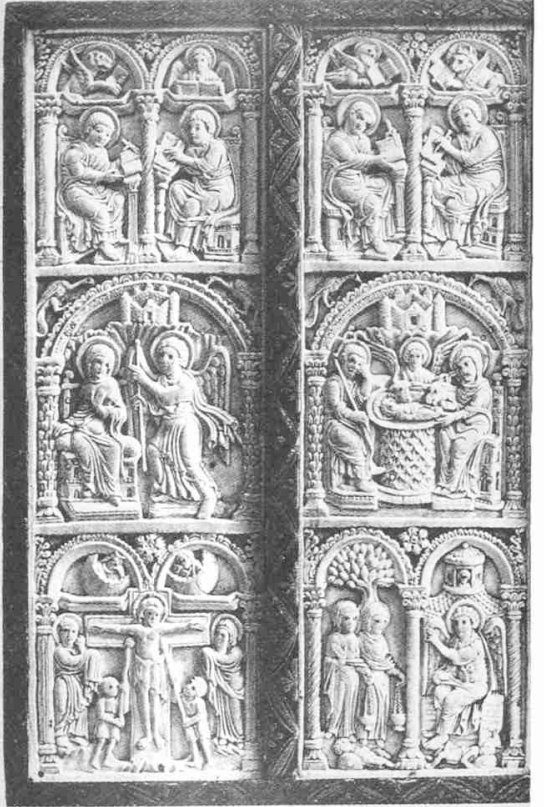

Ilustracja 9
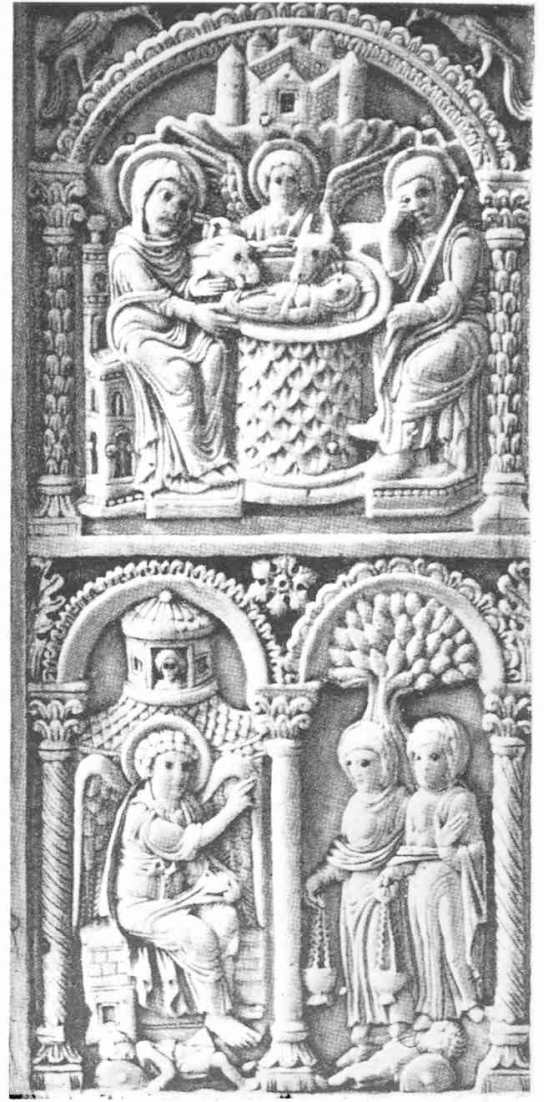

Ilustracja 9a 


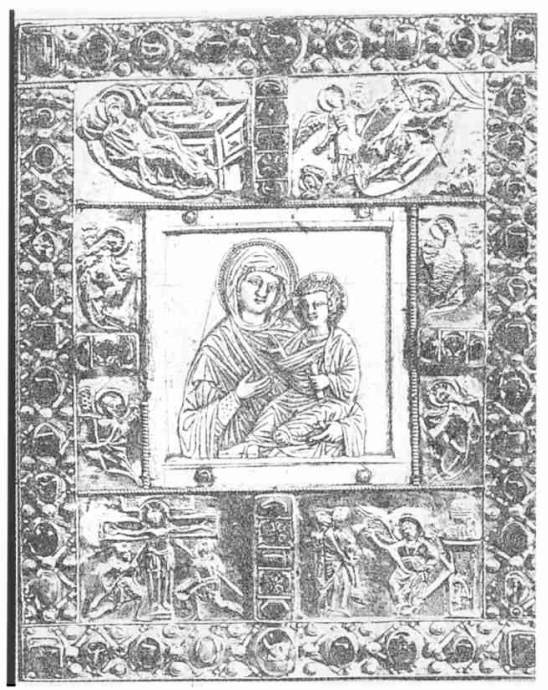

Ilustracja 10

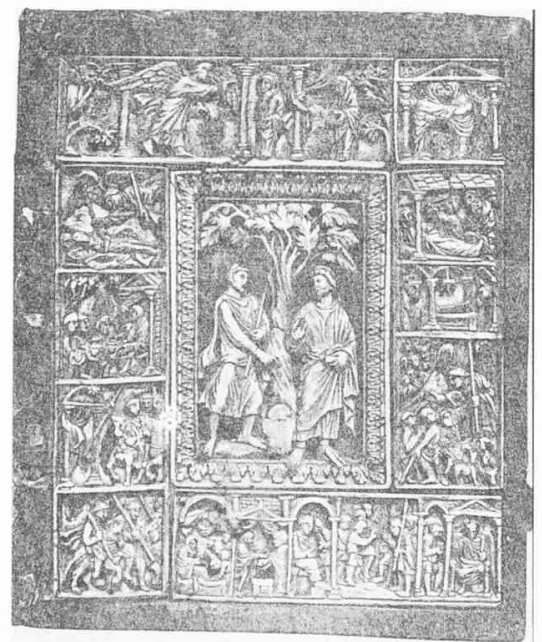

Ilustracja 12

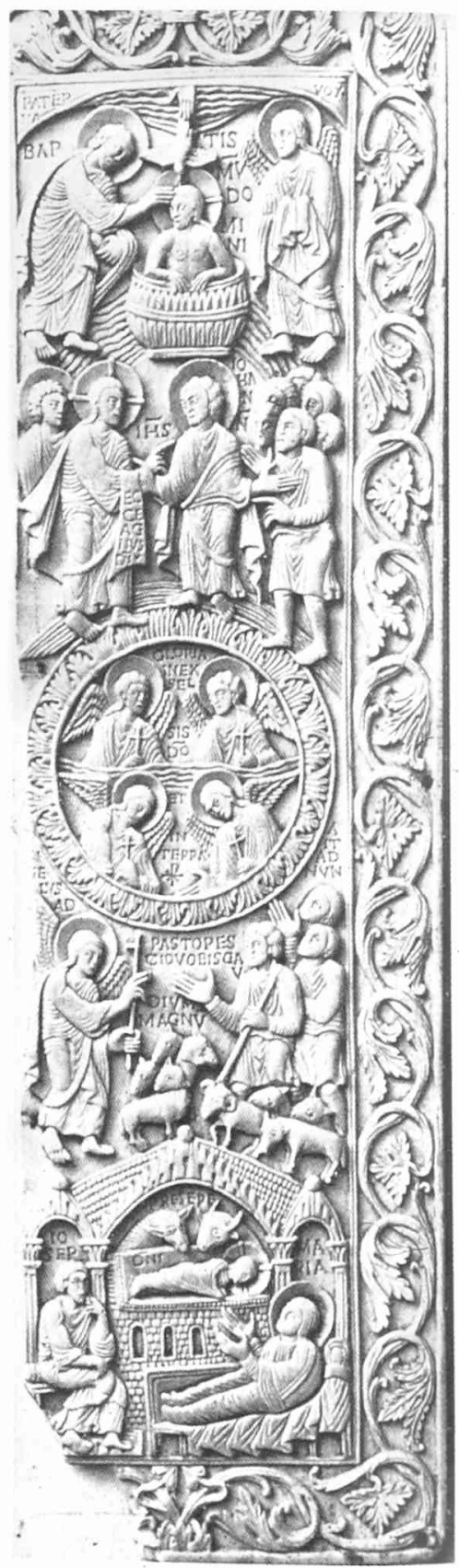

Ilustracja 11 

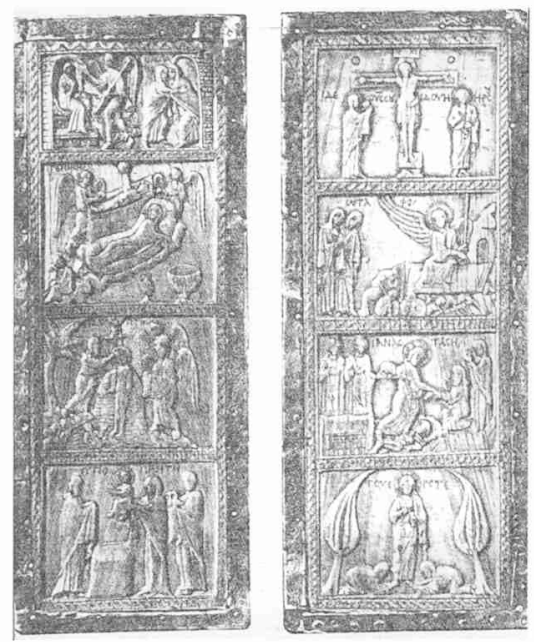

Ilustracja 13

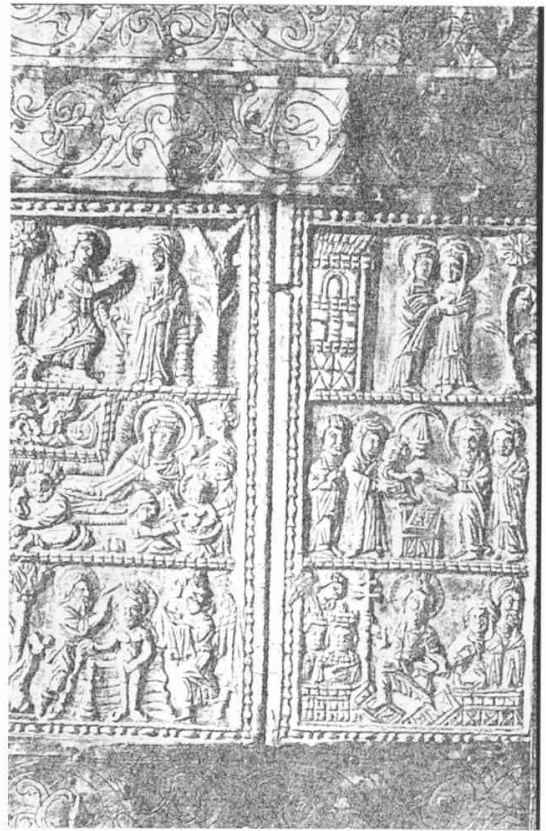

Ilustracja 14

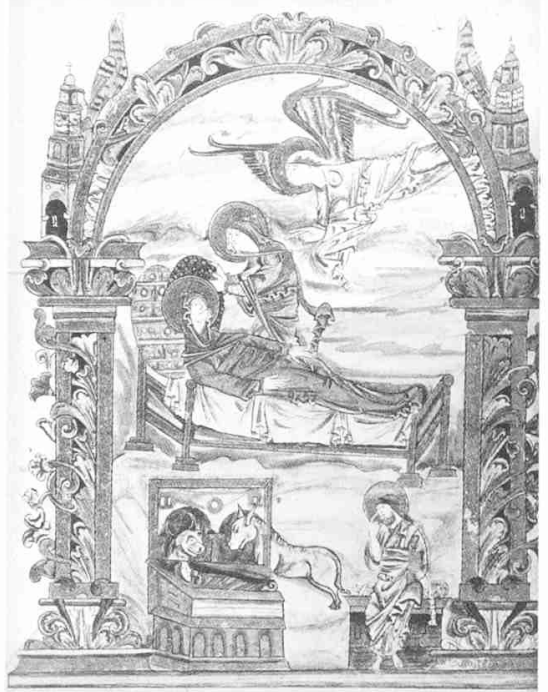

Ilustracja 16 


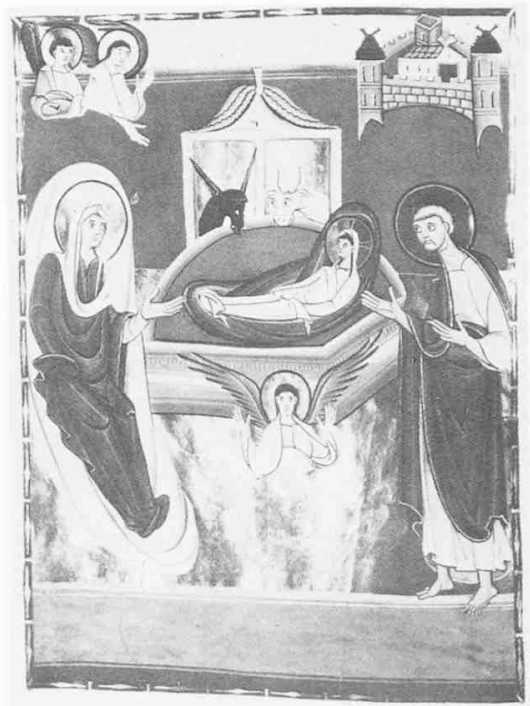

Ilustracja 17

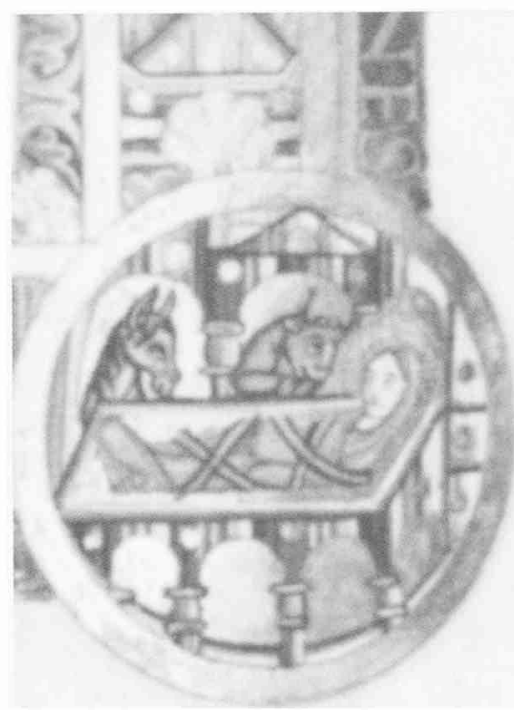

Ilustracja 18a

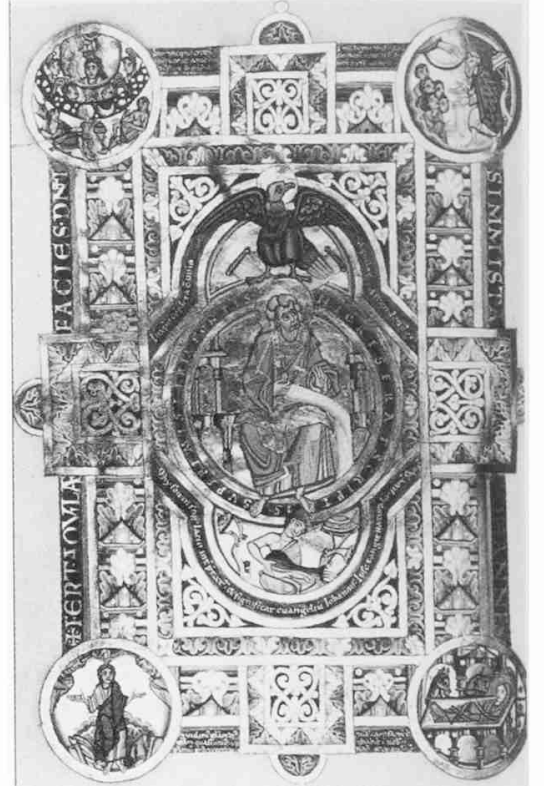

Ilustracja 18

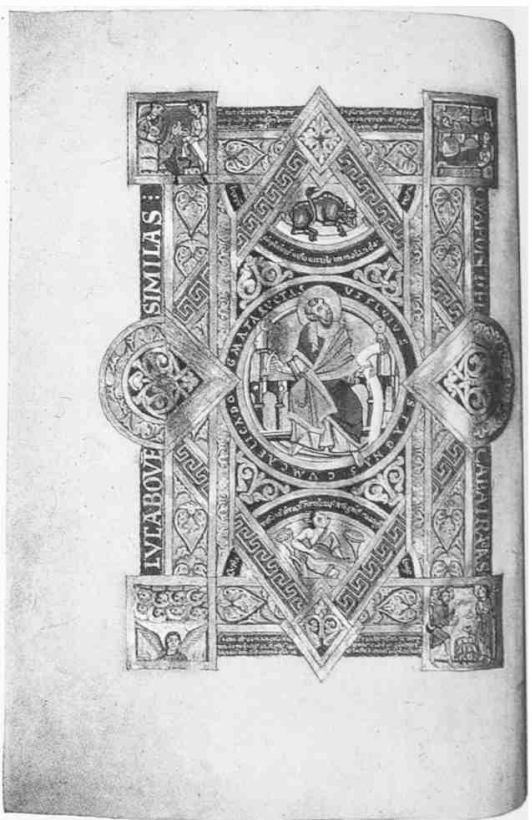

Ilustracja 19 

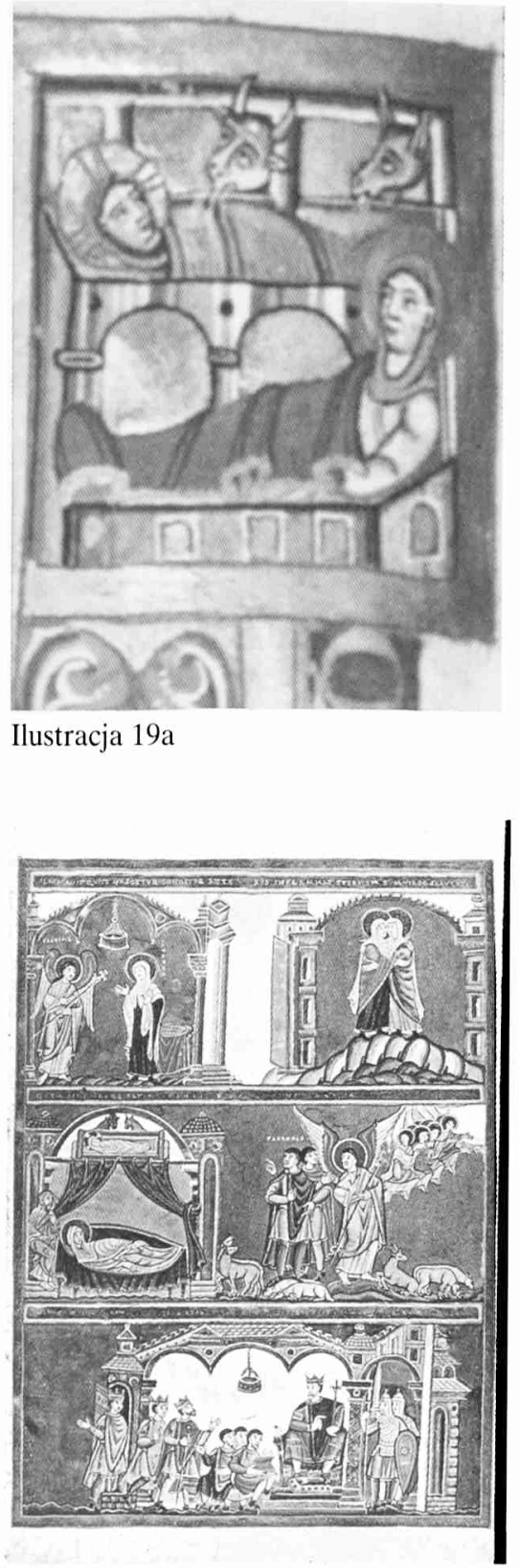

Ilustracja 21

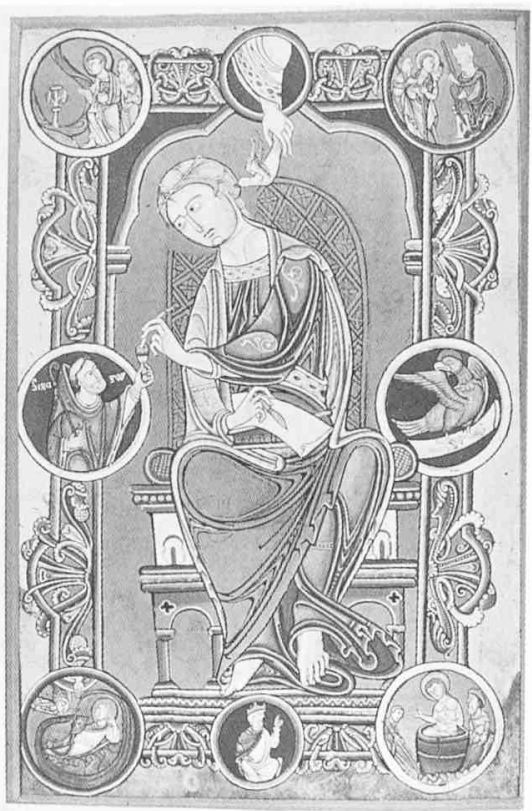

Ilustracja 20

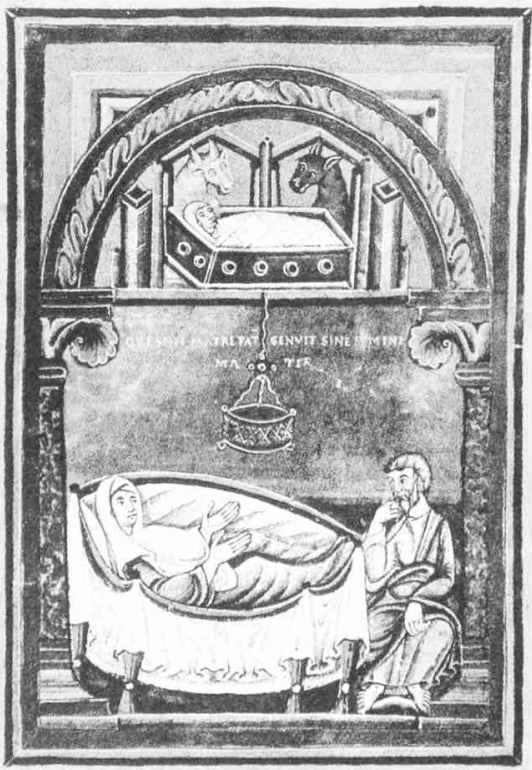

Ilustracja 22 


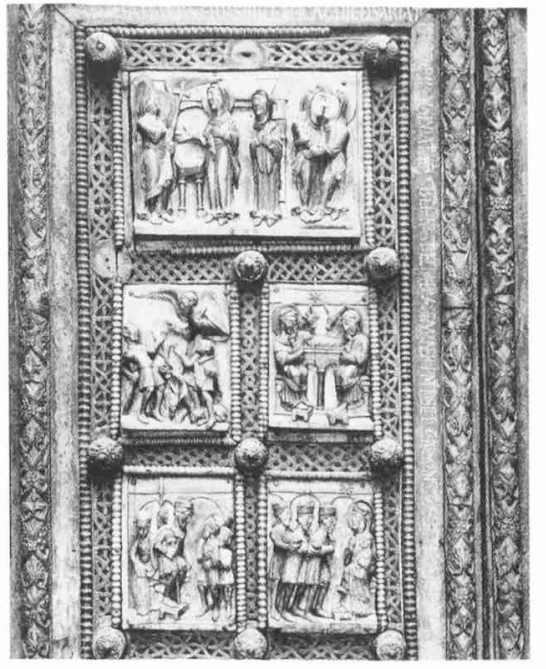

Ilustracja 23

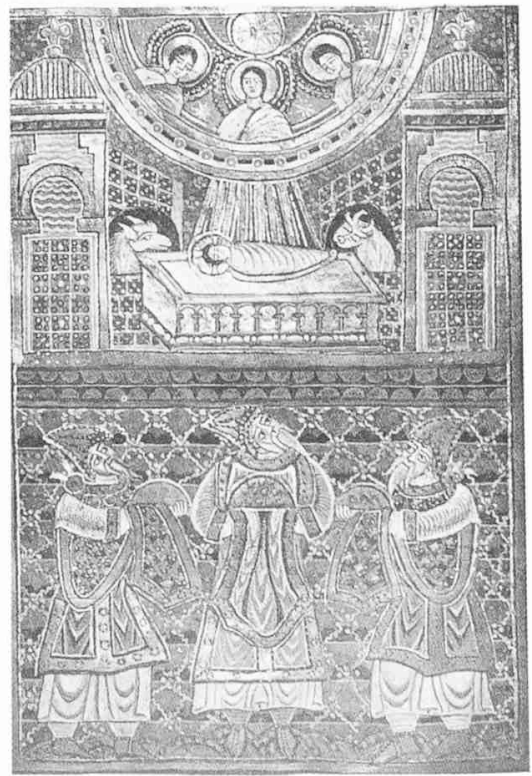

Ilustracja 25

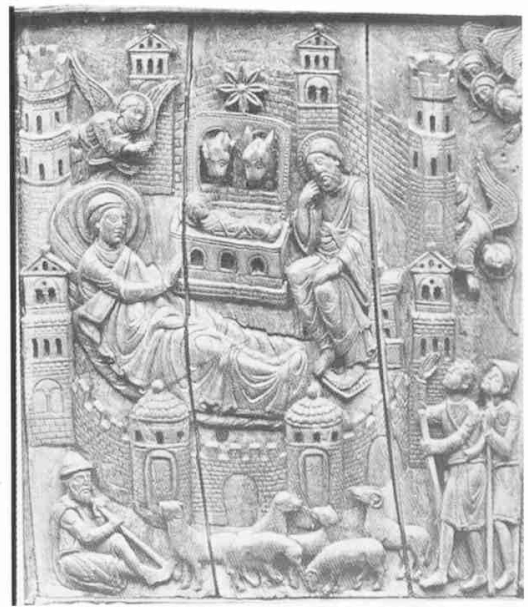

Ilustracja 24

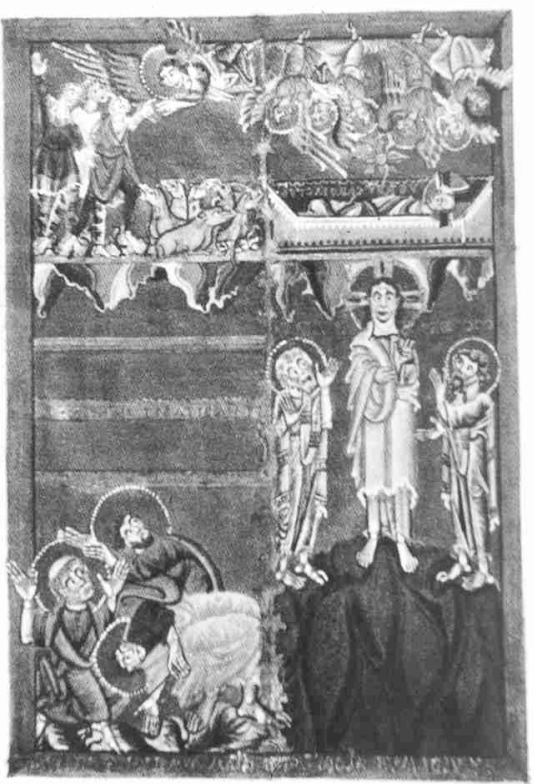

Ilustracja 26 


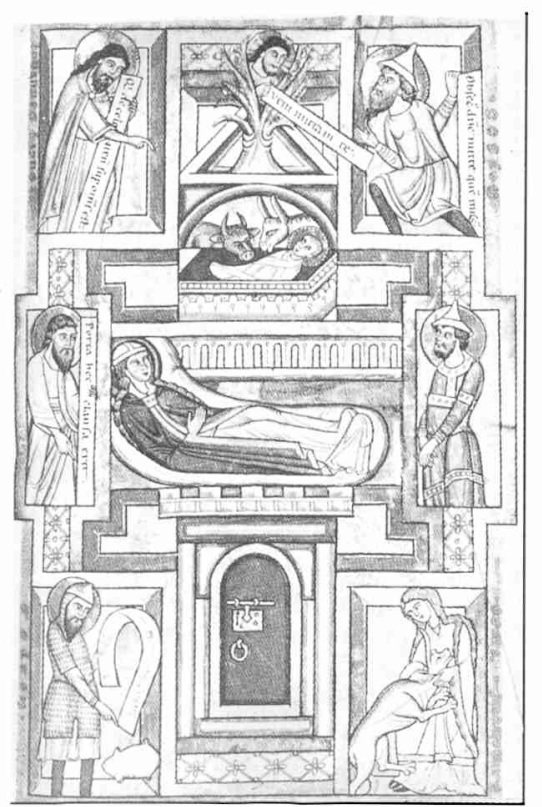

Ilustracja 27

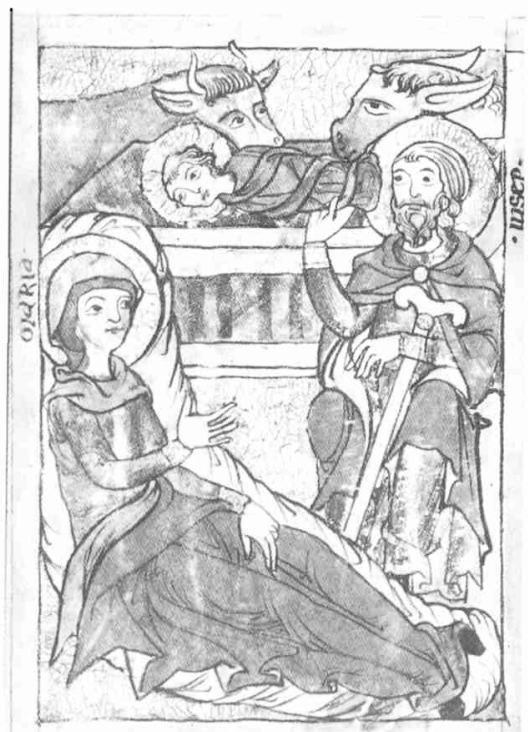

Ilustracja 29

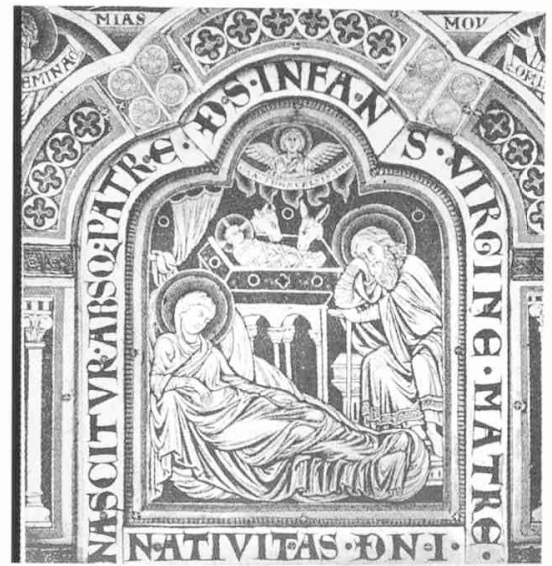

Ilustracja 28

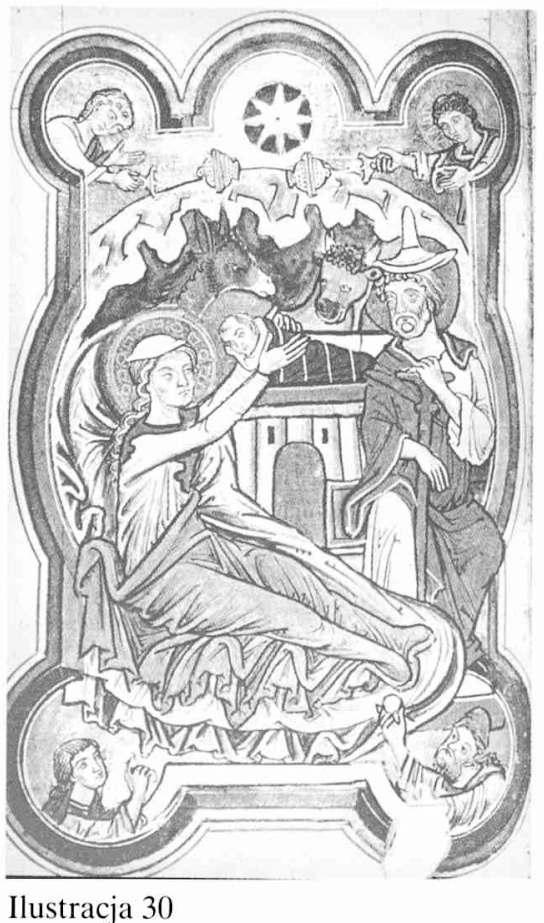




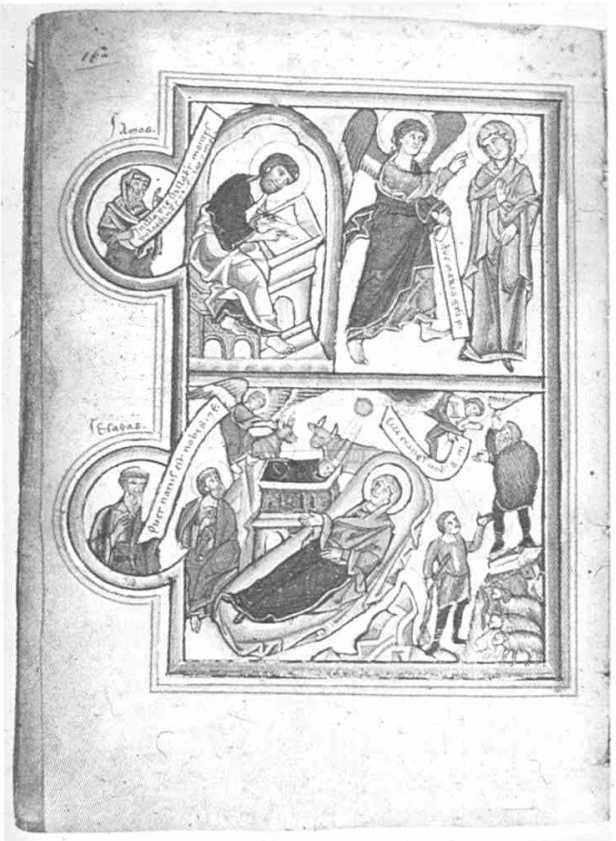

Ilustracja 31

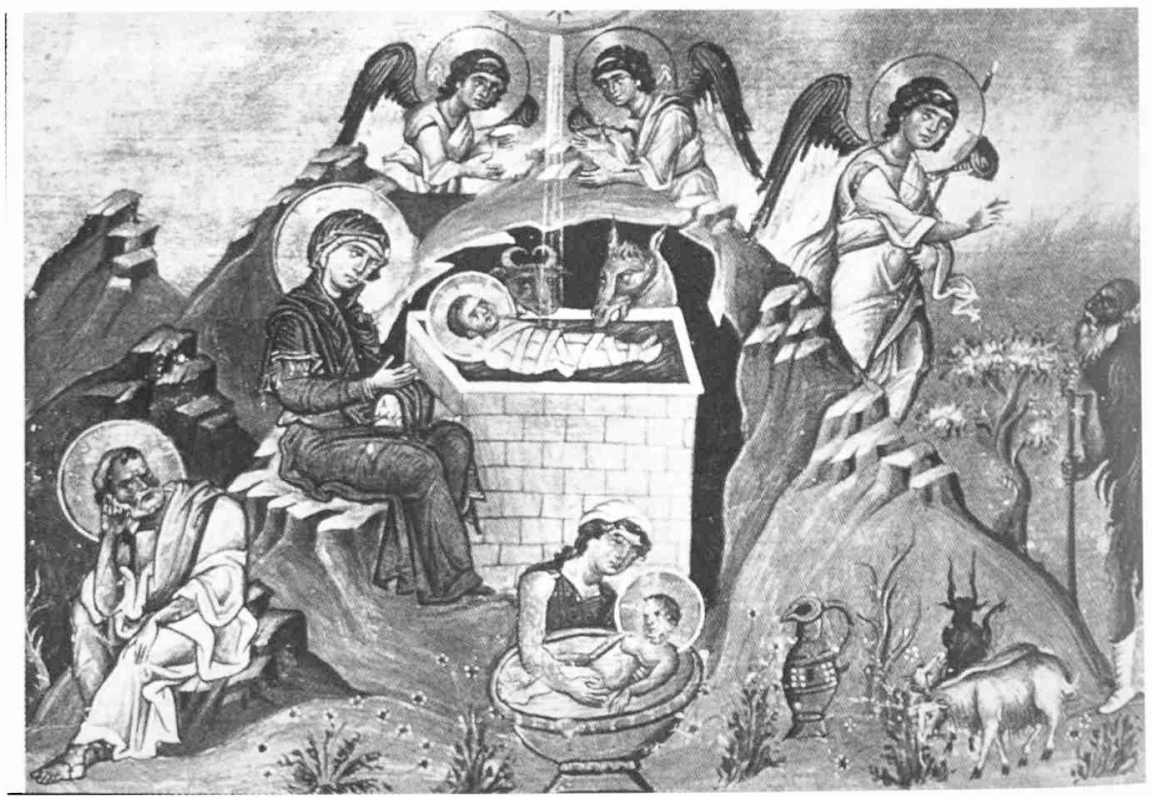

Ilustracja 32 


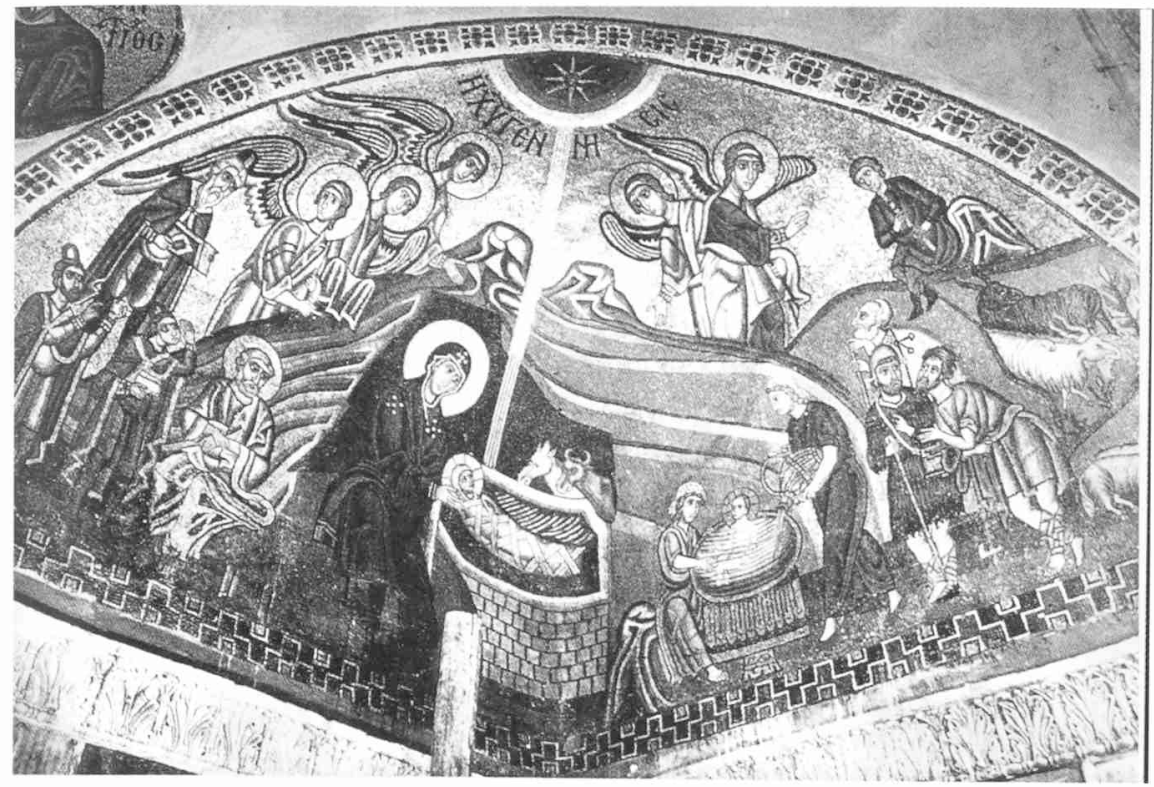

Ilustracja 33

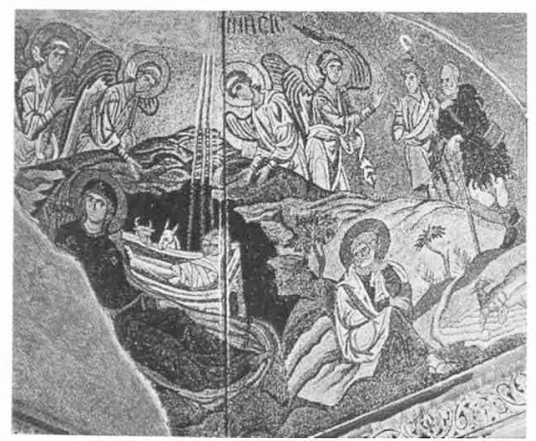

Ilustracja 34
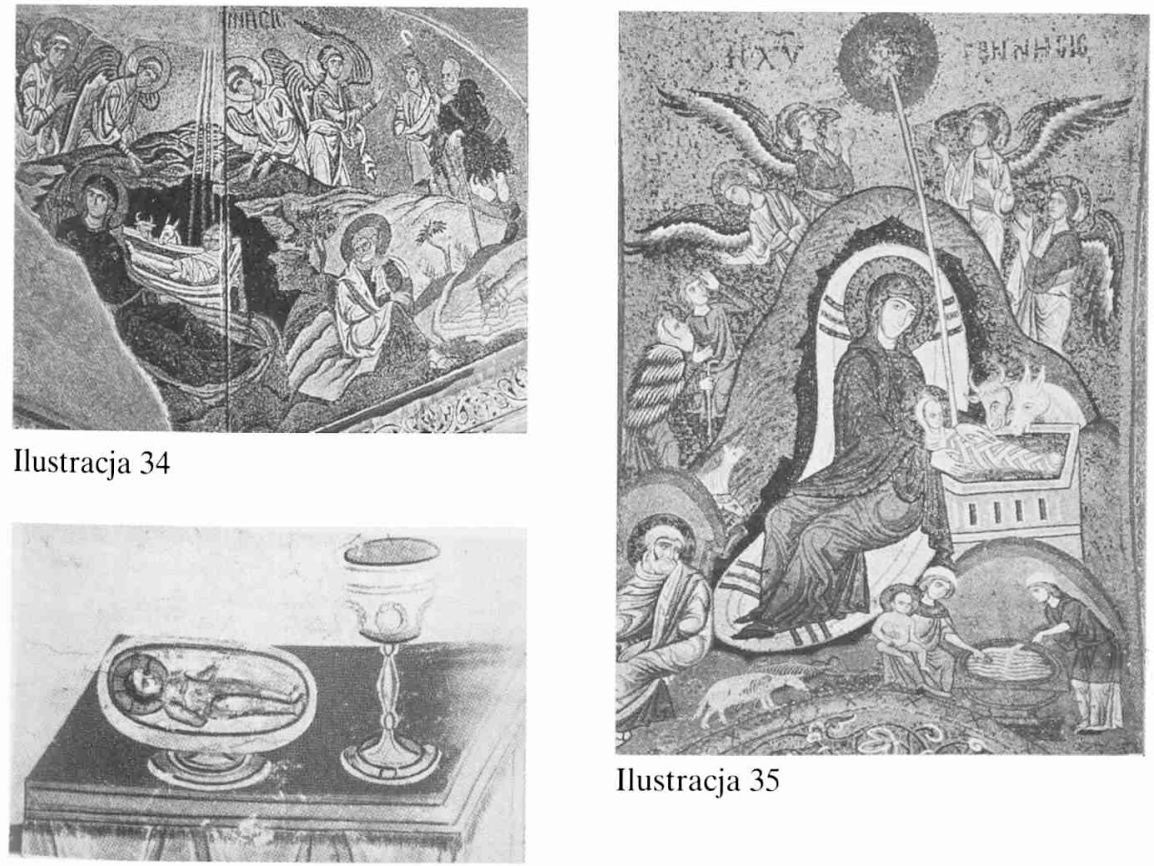

Ilustracja 35

Ilustracja 36 


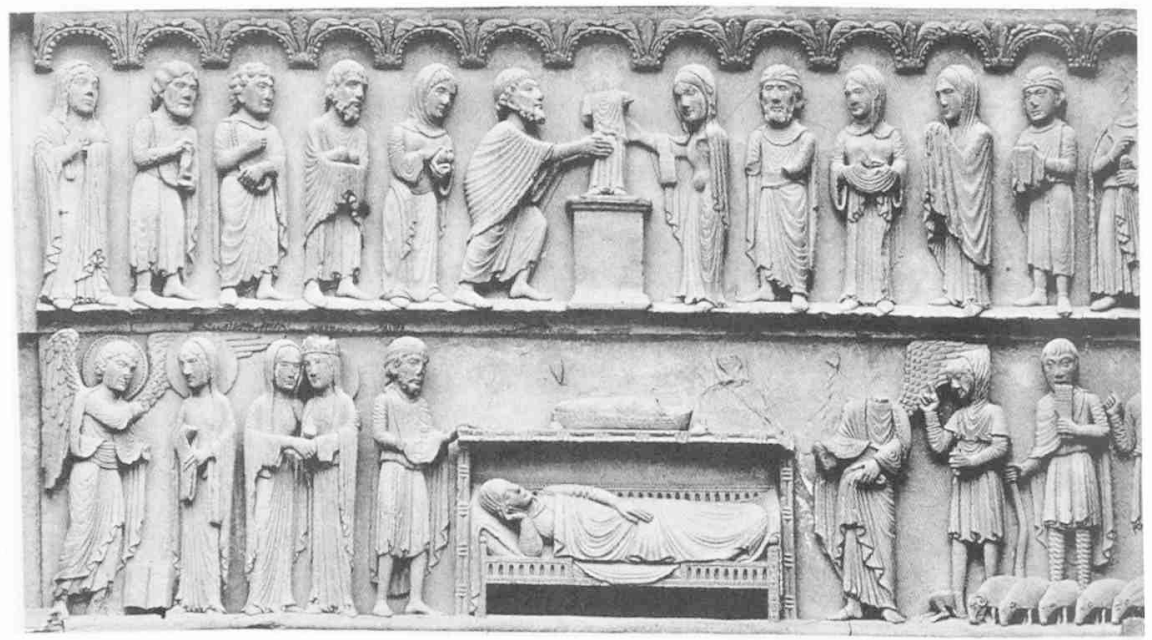

Ilustracja 37

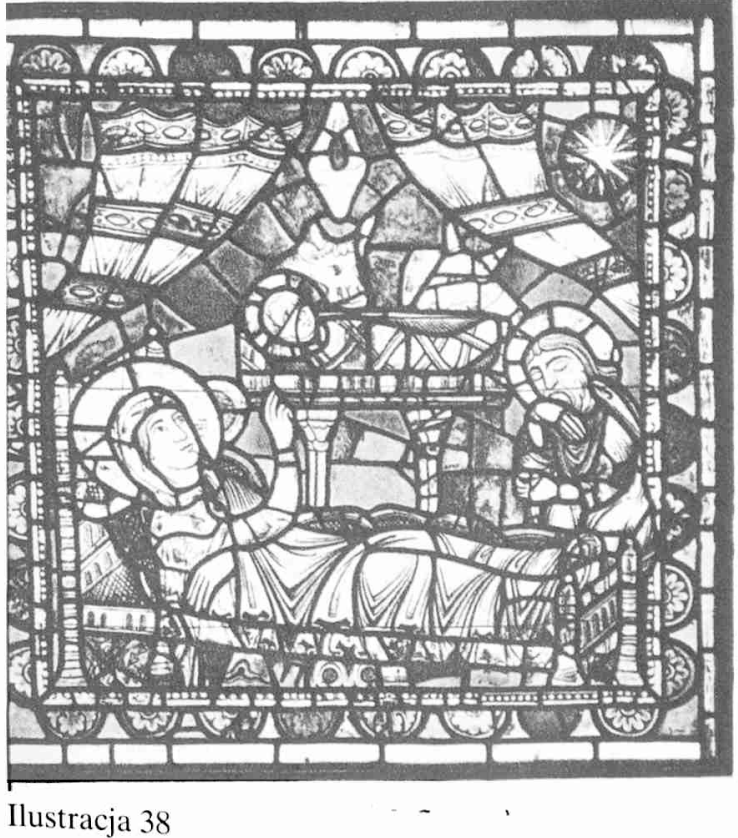


Codex Aureus Epternacensis datowany na poł. XI wieku, zamówiony przez Henryka III dla katedry w Echternach (il. 21), powraca do znanego nam motywu postaci Dzieciątka odseparowanego od postaci Maryi ${ }^{20}$. Tutaj Dzieciątko doznało uroczystego wyniesienia, natomiast Maryja pozostała u podnóża tej sakralnej konstrukcji. Ważnym symbolem określającym scenę jako Revelatio w teologicznym znaczeniu, jest odsłonięta kotara, zmysłowy znak objawionej tajemnicy przyjścia Chrystusa. Nadejście to jest zstąpieniem z nieba, co oddane zostało w kompozycji przez wyniesienie ponad Maryję żłóbka w kształcie ołtarza. Mistyczny sens ciała Chrystusa, podkreślają także inne znaki symboliczne: półkolisty, niszowy układ miejsca złożenia Chrystusa, pozbawiony został barwy. W średniowiecznym malarstwie treści transcendentne bezpośrednio odnoszące się do Boga, podkreślano barwą złotą lub białą. W miniaturze biała nisza jako miejsce złożenia Dzieciątka, jednoznacznie określa ciało Jezusa jako ciało mistyczne.

Zatem przy zachowaniu bizantyńskich pierwowzorów dostrzegamy tutaj rozwiązania nowe, które łączą się z Objawieniem Boga w osobie Chrystusa. Naśladownictwa tego rodzaju kompozycji utrwalone zostały w miniatorstwie oraz w plastyce XI i XII wieku. Na miniaturze pochodzącej z poł. XI wieku (il. 22, Bruksela, Bibl. Royal, 9428 fol. 7) diadem zawieszony ponad Maryją wskazuje na jej królewskie pochodzenie oraz świętość Narodzenia. Prosty schemat żłóbka, wpisanego w arkadzie, jest asocjacją do Dzieciątka jako daru nieba. Na reliefie drewnianych drzwi z kościoła NMP na Kapitolu w Kolonii z poł. XI wieku (il. 23) przemyślany został maryjny program ikonograficzny w całym układzie scen. Maryja jest tutaj Matką Chrystusa człowieka i Matką Boga. Pogrążona jest w kontemplacji, podobnie jak św. Józef.

Plastyka 2 poł. XI wieku przejęła ideę Bożego Narodzenia jako wydarzenia historycznego, związanego jednocześnie z transcendentnym wymiarem Objawienia się Boga w Chrystusie. Podkreślone zostały wątki Apokaliptycznego Przyjścia oraz Eucharystycznego zstępowania ciała na ołtarzu mistycznym ${ }^{21}$. Na plakietce pochodzenia kolońskiego, wykonanej z kła morsa z końca XI lub pocz. XII wieku (il. 24) scena Bożego Narodzenia znalazła się w obrębie murów miasta. Tak precyzyjnie zakreślony obwód z bramami zaznaczającymi ośmiokątny układ obwodu, implikuje jedyne miasto w ten sposób przedstawiane, mianowicie Jeruzalem Niebieskie ${ }^{22}$. Było ono na wielu obrazach znakiem czasów Paruzji, miejscem spełnienia się ludzkich dziejów w czasach ostatecznych. Analogiczny jest sens miniatury z Ewangeliarza biskupa Barnwarda (il. 25) z Dzieciątkiem złożonym na ołtarzu, ponad którym pojawia się popiersie Chrystusa w chwale niebieskiej. Poza obwodem architektury miasta zjawia-

\footnotetext{
${ }^{20}$ Por. R. Calkins, dz. cyt. s. 160.

${ }^{21}$ Por. J. Meyendorf, dz. cyt. s. 157.

22 Por. N. Schneider, dz. cyt. s. 95.
} 
ją się postaci poszukujących Mędrców, których uniesione w górę głowy wskazują na znaczenie sceny, jako Objawienia się Boga ludzkości. Koloński malarz miniatury z 2 ćw. XI wieku, ukazał Boże Narodzenie połączone ze scenami: Zwiastowaniem pasterzom oraz sceną Przemienienia (il. 26). Bogate związki wcielenia z Objawieniem przekazanym w Starym Testamencie, pogłębiło kontekst boskości Chrystusa oraz rozumienia Maryi jako Theotokos. Na miniaturze Missale ze Stammheimm (lata 1120-1180, il. 27), umiejscowiona została postać Chrystusa pomiędzy Objawieniem się Boga Mojżeszowi w krzewie ognistym, a Gideonem i Maryją z jednorożcem. Poniżej leżącej Maryi wyeksponowana została zamknięta brama, bezpośrednio określająca Dziewicę jako Porta Clausa zgodnie z proroctwem Izajasza.

Wypracowane w okresie wczesnoromańskim oraz romańskim wzorce obrazowego unaocznienia związku Przyjścia Chrystusa jako człowieka i jednocześnie Jego Objawienia się jako Boga człowiekowi, zachowało swoją aktualność w dziełach przełomu stylu romańskiego z gotykiem. Bizantynizujący schemat zachowywał oddalenie Maryi od Jezusa złożonego na wysokim ołtarzu jak przedstawił to mistrz Mikołaj $\mathrm{z}$ Werdun na ołtarzu $\mathrm{z}$ Klosterneuburga z 1181 roku, którego bizantyńskie inspiracje rozpoznano także w wielu innych scenach tego antepedium (il. 28) ${ }^{23}$. Trwałość takiego układu potwierdza szereg kompozycji miniatorstwa niemieckiego np. Psałterza z Regensburga (il. 29), Psałterza ze środkowej Saksonii (il. 30) oraz Ewangeliarza z Salzburga (il. 31). Wpływ sztuki bizantyńskiej na łacińską Europę zaznaczył się w X wieku i utrwalił w wiekach XI oraz XII. Należałoby omówić w odrębnej pracy istotę scen Bożego Narodzenia w bizantyńskim kręgu sztuki, wspierając się w interpretacji tekstami liturgicznymi oraz teologicznymi. Możemy jedynie wskazać tutaj na najbardziej istotne przykłady dzieł powstałych w okresie poikonoklastycznym, czyli takim który odpowiada rozkwitowi sztuki łacińskiej od karolińskiej poczynając. Menologion cesarza Basileusa II powstał w Konstantynopolu w 2 poł. IX wieku (il. 32), zaliczany jest do najbardziej wytwornych iluminacji oddziaływujących na miniatorstwo bizantyńskie. Zawarta w nim scena Bożego Narodzenia może nam potwierdzić genezę łacińskich obrazów wyżej przytoczonych. Żłóbek jest murowanym ołtarzem, na którym złożone zostało Dzieciątko. Ten typ przyjęli greccy artyści mozaik np. w klasztorze św. Łukasza z pocz. XI wieku (il. 33), z Dafni z XII wieku (il. 34) oraz z Palermo z roku 1143 (il. 35). Z jaką konsekwencją podtrzymywali bizantyńscy malarze eucharystyczny aspekt wcielenia Chrystusa, świadczy dzieło z klasztoru w Chiliandra z pocz. XIV wieku (il. 36), ukazujące Dzieciątko złożone na patenie, która wraz $\mathrm{z}$ kielichem wskazuje na liturgię eucharystyczną.

Ostatnim oddechem romańskiego wzorca scenicznego konserwującego historyczny i zarazem transcendentny wymiar wcielenia była monumentalna rzeź-

${ }^{23}$ Por. L. Grodecki, Le Moyen Age retrouve, Paris 1986, 389 nn. 
ba katedr gotyckich. W stopniu skondensowanym, w syntezie ubiegłych wieków, obrazy powtarzając romańskie wzorce jednocześnie je zmonumentalizowały, pogłębiając tym samym ich eklezjalny sens. Katedra w Chartres w tympanonie zachodnim portalu prezentuje scenę Inkarnacji z Maryją leżącą na łożu, zaś Dzieciątko umieszczone zostało na jego górnej listwie (il. 37). Tradycyjny sposób ukazuje także witraż w tejże katedrze z roku 1194 (il. 38), na którym obserwujemy identyczny niemal schemat kompozycyjny jaki prezentowała miniatura z kodeksu z Echternach (il. 21), gdzie kotara jest elementem symbolicznym, odsłaniającym tajemnicę Zbawienia. Obrazy scen Bożego Narodzenia w sztuce wczesnoromańskiej i romańskiej odsłaniają sens wcielenia w kontekście przyjścia Chrystusa jako człowieka i jako Boga, dlatego znajdują odniesienie do innych scen, które tę podwójną naturę Chrystusa potwierdzają. Kąpiel Dzieciątka - Chrzest Chrystusa, następnie Pasja i śmierć znajdują sens w Zmartwychwstaniu i Eucharystii.

\section{ICONOGRAPHY OF INCARNATION IN THE EARLY CHRISTIAN AND ROMANESQUE ART ON THE EXAMPLE OF THE SELECTED SCENES OF CHRISTMAS}

(Summary)

In the art the Theme of Incarnation was illustrated in a rich scenic repertiore creating its prototypes at the early - Romanesque and Romanesque period. It was also the time of dynamically forming motifs in the art that defined the Gothic art and to a high degree modern one. In the fine arts such a model of Incarnation was made by Christmas scene. This scene has its origin in the early Christian and early -Byzantine fine art developed in the Italian circle and eastern -Syro - Palestinian. In these early paintings historical evangelical teaching was enriched with some other contents in order to emphasize Christmas in the context of Baptism, Passion of Christ of Resurrection. Connection between these scenes is deepened by sense of Incarnatin as the union of humanity and Divinity in Christ as well as in history and transcendence. The selected examples of works created between the IV th and VI th century like, a reliquary of the Holy Land, diptych from Milan, diptych from Murano make models for the IX th -XII th century painting and sculpture, The Carolingian and Ottonian art deepened the apocalyptic contents expressed in the Christmans scenes exemplified by miniatures and codices covers - most often Bibles e.g. from Aix-la-Chapelle, Frankfurt or miniatures of Egbert s Codex, Biblie from Echternach, the Books of Pericope of emperor Henry II. Composition of a crib as sarcophagus and altar provides basic meaning that sets Eucharistic sense in the Christmas scenes. Permanence of this relation is testified by monumental sculptures of Gothic cathedrals portals that reached the sources of the Romanesque art. 